Original research article

Food Quality and Functionality Section

\title{
Effect of Core Temperature on the Oxidation of Lipids and Proteins During Steam Cooking of Large-Mouth Bass (Micropterus salmoides)
}

\author{
Keyu Wang ${ }^{1,2}$, Yulong Bao ${ }^{1 *}$, Hongxu Yang ${ }^{1}$, Yong Wang ${ }^{3}$, Dongpo Chen ${ }^{3}$, Joe M. Regenstein ${ }^{4}$, Peng Zhou ${ }^{1}$ \\ ${ }^{1}$ State Key Laboratory of Food Science and Technology, Jiangnan University, Wuxi 214122, China \\ ${ }^{2}$ School of Food Science and Technology, Jiangnan University, Wuxi, China \\ ${ }^{3}$ Hangzhou Robam Appliances Co., Ltd., Hangzhou, China \\ ${ }^{4}$ Department of Food Science, Cornell University, Ithaca, USA
}

Key words: large-mouth bass, steam cooking, lipid oxidation, protein oxidation, volatile compounds, in vitro digestibility

Steam cooking is a popular way of preparing fish and the end temperature plays a key role in the quality of the cooked fish. In this study, the lipid and protein oxidation, and the related changes in volatile compounds and in vitro digestibility of large-mouth bass (Micropterus salmoides) steam cooked to a core temperature of $45^{\circ} \mathrm{C}^{\circ} \mathrm{C}, 55^{\circ} \mathrm{C}, 65^{\circ} \mathrm{C}, 75^{\circ} \mathrm{C}$, and $85^{\circ} \mathrm{C}$ were investigated. Steaming caused a significant increase in the peroxide value (PV) and the thiobarbituric acid-reactive substances (TBARS) value, accompanied by the decreased proportion of unsaturated fatty acids like oleic acid and linoleic acid, which was related to the lipid oxidation and the increase in volatile aldehydes as indicated by the partial least squares analysis. The protein oxidation can be reflected by the significant decrease of total thiol groups, combined with the aggregation as shown in SDS-PAGE and the increase in particle size at pre-digestive phase. And the aggregation of proteins further caused the decreased digestibility of fish meat at the gastric phase, especially when the core temperature was above $75^{\circ} \mathrm{C}$. Furthermore, steaming significantly decreased the aerobic count, and no coliform or generic $E$. coli was detected in steamed samples. Thus, the core temperature of $65-75^{\circ} \mathrm{C}$ was recommended for the consideration of food oxidation and microbial safety.

\section{INTRODUCTION}

Cooking is used to eliminate foodborne microorganisms, especially pathogens, and to improve the sensory properties of foods. Steaming as a traditional cooking method helps in maintaining the nutrition and original flavor of food, and also reducing the generation of harmful compounds compared with other cooking methods [Hu et al., 2018; Maulvault et al., 2012].

Cooking also leads to the formation of reactive oxygen species (ROS), which contribute to the oxidation of lipids and proteins [Sobral et al., 2018]. With the development of free radical chain reactions, lipids are oxidized in three simultaneous phases of initiation, propagation and completion, which not only reduces their nutritional value, but also causes the loss of other lipo-soluble bioactive compounds and the impaired eating quality [Chaiyasit et al., 2007; Guyon et al., 2016]. The oxidation of lipids first gives rise to the primary products such as hydroperoxides and conjugated dienes, and these compounds will be further decomposed, which are related to the increase of some volatile compounds like aldehydes, ketones, and alcohols [Souza \& Bragagnolo, 2014].

\footnotetext{
* Corresponding Author:Tel.: +86-130-0337-6496;

E-mail: yulong.bao@jiangnan.edu.cn (Yulong Bao)
}

As for protein oxidation, it can be induced by the ROS directly or by the secondary products of oxidative stress, and is also an important issue in food research [Soladoye et al., 2015]. Thermal treatments can further intensify the oxidative modification of protein, for instance, cysteine oxidation can lead to the formation of intermolecular disulfide, and the oxidation of basic amino acids induces the formation of carbonyl groups, the cross linking of carbonyls and free amino groups promotes the content of protein aggregates, which are considered as poor substrates for proteases and may impair the digestibility of protein [Hu et al., 2018; Sun et al., 2011]. In addition, the protein oxidation products, like kynurenines and $\alpha$-aminoadipic semialdehyde, present a negative impact on human health [Kjærsgård et al., 2006]. Some studies suggested that the accumulation of oxidized proteins in the human body, which had the cytotoxic and mutagenic potential, would contribute to the aging and age-related diseases [Berlett \& Stadtman, 1997; Estévez \& Luna, 2017]. Therefore, the appropriate cooking condition and the control of food oxidation are crucial during the domestic cooking.

According to recent studies, researches have often focused on the effects of cooking methods on food oxidation, particularly for the livestock and poultry [Lorenzo \& Domínguez, 2014; Silva et al., 2016]. Hu et al. [2017] investigated the lipid and protein oxidation of farmed sturgeon (Acipenser gueldenstaedtii) under different cooking methods and con- 
cluded that compared with frying and roasting, steaming significantly decreased the formation of carbonyls and increased the amounts of free thiols. However, protein and lipid oxidation of fish during the steaming process and their correlations with the changes of other physicochemical properties have received much less attention.

Large-mouth bass (Micropterus salmoides) is an important commercial fish species in China, because of its rapid growth and high market value [Yuan et al., 2014]. The growth rate of large-mouth bass yield has reached the highest among all the freshwater fish species in recent years, with the annual production estimated at 457,000 tons in 2017 . It is generally prepared by steaming and is also favored by consumers for its high nutritional value and excellent taste. As mentioned before, protein oxidation is undesired. Generally, a lower degree of cooking leads to a lower level of food oxidation. But insufficient cooking poses a threat to human health due to pathogens. The hypothesis of this study was that large-mouth bass could be steam-cooked to optimal degree, so that the fish is safe to eat, while the food oxidation is kept at a relatively low level. In order to test this hypothesis, lipid and protein oxidation of large-mouth bass were monitored when steamed to different core temperatures, and their potential relationships with the formation of volatile compounds and in vitro digestibility were explored.

\section{MATERIALS AND METHODS}

\section{Materials}

Live large-mouth bass $(25 \pm 1 \mathrm{~cm}$ in length, $378 \pm 27 \mathrm{~g}$ in weight) was purchased from Vanguard Market (Wuxi, Jiangsu, China) in May and June, 2018. The bicinchoninic acid (BCA) protein assay kit was purchased from Thermo Fisher Scientific (Shanghai, China). Standards for 37 fatty acid methyl ester mixture (C4-C24), 14\% boron trifluoridemethanol, $\alpha$-amylase (from Bacillus licheniformis, $720 \mathrm{U} / \mathrm{mg}$ protein, CAS: 9000-85-5), pepsin (from porcine gastric mucosa, $3706 \mathrm{U} / \mathrm{mg}$ protein, CAS: 9001-75-6), pancreatin (from porcine pancreas, CAS: 8049-47-6), bile salts, and 2,4,6-trimethylpyridine were obtained from Sigma-Aldrich (Shanghai) Trading Co., Ltd. (Shanghai, China). The 5,5'-dinitrobis[2-nitrobenzoic acid] (DTNB), ethylenediaminetetraacetic acid (EDTA), urea, acrylamide, and bisacrylamide were purchased from Sangon Biotech (Shanghai) Co., Ltd. (Shanghai, China). All other chemicals used were of analytical grade and were from Sinopharm Chemical Reagent Co., Ltd. (Shanghai, China).

\section{Preparation of samples}

The fish were killed after head stunning, internal organs and scales were removed, then transported on ice to the laboratory within half an hour. After rinsing with tap water, they were randomly divided into 6 groups, the first uncooked group was the control, and the other 5 groups were steam cooked to different core temperatures. Each group contained twelve fish for the measurement of related indicators.

Briefly, a thermometer (K-type, UT 322, Uni-Trend Technology Co., Ltd., Dongguan, Guangdong, China) was inserted into the center of the fish sample (the position where the tem- perature changed the slowest). Then the fish were each placed on a porcelain dish and cooked to a core temperature of $45^{\circ} \mathrm{C}$, $55^{\circ} \mathrm{C}, 65^{\circ} \mathrm{C}, 75^{\circ} \mathrm{C}$, and $85^{\circ} \mathrm{C}$ at $100^{\circ} \mathrm{C}$ steam using a steam oven (Model S226, Hangzhou Robam Appliances Co., Ltd., Hangzhou, Zhejiang, China), and the corresponding average steaming time was 9.7, 12.2, 14.3, 18.2, and $22.5 \mathrm{~min}$, respectively. When the core temperature reached the target value, samples were taken out from the oven and cooled at room temperature to around $25^{\circ} \mathrm{C}$. The cooking loss was measured with the whole fish, then the fish muscle was immediately used for the determination of $\mathrm{pH}$, differential scanning calorimetry (DSC) profile, protein solubility, volatile compounds, in vitro digestibility, and microbiological analysis. Some of the samples were lyophilized using a vacuum freeze drier (BenchTop Pro, SP Scientific, Warminster, PA, USA) for the analysis of peroxide value (PV), thiobarbituric acid-reactive substances (TBARS) value, and the composition of fatty acids, and the reminder was stored at $-70^{\circ} \mathrm{C}$ until the determination of the carbonyl contents, total thiols, and SDS-PAGE analysis, a maximum of three weeks.

\section{Cooking loss}

Samples were weighed before and after steaming, the surface was dried before weighing, and the cooking loss was calculated as:

$$
\text { Cooking loss }(\%)=\frac{\text { raw weight }(\mathrm{g})-\text { cooked weight }(\mathrm{g})}{\text { raw weight }(\mathrm{g})} \times 100
$$

pH

The $\mathrm{pH}$ was measured using a S220 Seven Compact $\mathrm{pH} /$ ion meter (Mettler-Toledo Inc., Columbus, OH, USA) with a suspension resulting from homogenizing 5-g samples at 21,200 rpm with $45 \mathrm{~mL}$ distilled water for $1 \mathrm{~min}$ (T10, IKAWerke, Staufen, Germany) and mixing for $30 \mathrm{~min}$ on a magnetic stirrer (RO 10, IKA-Werke, Staufen im Breisgau, Germany).

\section{Peroxide value}

The PV was measured using the method of Mi et al. [2016] with a slight modification. A $\sim 0.5$ g lyophilized sample was mixed with $15 \mathrm{~mL}$ of a chloroform-methanol solution $(2: 1, v / v)$ for lipid extraction. Then an aliquot from the chloroform layer $(1 \mathrm{~mL})$ was reacted with $50 \mu \mathrm{L}$ ferrous chloride $(3.5 \mathrm{~g} / \mathrm{L})$ followed by reaction with $50 \mu \mathrm{L}$ potassium thiocyanate $(300 \mathrm{~g} / \mathrm{L})$. The absorbance of the reaction mixture was measured at $500 \mathrm{~nm}$ after $5 \mathrm{~min}$, and ferric chloride solution $(10.0 \mu \mathrm{g} / \mathrm{mL})$ was used for the standard curve. The results are expressed as milliequivalents of peroxide per kilogram of dry weight (meq peroxide/kg dry weight).

\section{Thiobarbituric acid-reactive substances}

TBARS method was used to estimate the content of thiobarbituric acid reactive substances, with malondialdehyde (MDA) as the standard [Ganhão et al., 2011]. Briefly, $1 \mathrm{~g}$ of a lyophilized sample was homogenized at 21,200 rpm with $15 \mathrm{~mL}$ of a $10 \%$ trichloroacetic acid solution and filtered through qualitative filter paper (92410441s, Sinopharm Chemical Reagent Co., Ltd., Shanghai, China). The filtrate $(5 \mathrm{~mL})$ was reacted with $5 \mathrm{~mL}$ of $0.02 \mathrm{M} \mathrm{TBA}$ at $100^{\circ} \mathrm{C}$ 
for $40 \mathrm{~min}$, and then measured at $532 \mathrm{~nm}$ after cooling for $15 \mathrm{~min}$. The results are expressed as mg MDA/kg dry weight.

\section{Fatty acid composition}

Lipids from the lyophilized sample $(0.5 \mathrm{~g})$ were extracted for $3 \mathrm{~h}$ using the chloroform-methanol method of Flaskerud et al. [2017], and nitrogen was used to limit the exposure to oxygen. Then, the chloroform layer was separated and dried under nitrogen. After saponification using a $0.5 \mathrm{~mol} / \mathrm{L}$ sodium hydroxide-methanol solution at $65^{\circ} \mathrm{C}$ for $30 \mathrm{~min}$ and methyl esterification using $14 \%$ boron trifluoride-methanol at $70^{\circ} \mathrm{C}$ for $10 \mathrm{~min}, 4 \mathrm{~mL}$ of hexane was used to extract the fatty acid methyl esters.

Fatty acid analysis was done on a GC-2010 Plus gas chromatograph (Shimadzu Co., Tokyo, Japan) with a DBWax column $(0.25 \mathrm{~mm} \times 30 \mathrm{~m}, 0.25 \mu \mathrm{m}$; Restek International, Bellefonte, PA, USA). The initial temperature of the column oven was held at $100^{\circ} \mathrm{C}$ for $3 \mathrm{~min}$, increased at $5^{\circ} \mathrm{C} / \mathrm{min}$ to $180^{\circ} \mathrm{C}$ and $3^{\circ} \mathrm{C} / \mathrm{min}$ to $240^{\circ} \mathrm{C}$. Fatty acids were identified by comparison of their retention times with a mixture of standards containing all the fatty acids identified in this experiment, and $5 \mathrm{mg} / \mathrm{mL}$ glyceryl triundecanoate was used as the internal standard.

\section{Volatile compounds}

Volatile compounds of large-mouth bass were determined using Headspace SPME-GC/MS according to the method of Yu et al. [2018]. Two grams of minced fish sample were mixed with $50 \mu \mathrm{g} / \mathrm{mL}$ internal standard 2,4,6-trimethylpyridine and $4 \mathrm{~mL}$ saturated $\mathrm{NaCl}$ solution, and headspace extraction using a SPME fiber $(50 / 30 \mu \mathrm{m}, \mathrm{DVB} / \mathrm{CAR} / \mathrm{PDMS}$, Supelco, Bellefonte, PA) was proceed at $45^{\circ} \mathrm{C}$ for $30 \mathrm{~min}$. Then, it was analyzed by a SCION SQ-456 GC/MS system (Bruker Daltonic Inc., Billerica, MA, USA) equipped with a DB-WAX column $(30 \mathrm{~m} \times 0.25 \mathrm{~mm} \times 0.25 \mu \mathrm{m}$; Agilent, Palo Alto, CA, USA). Xcalibur software was used to screen out the volatile substances with a matching degree greater than 800 based on the Wiley 7 and NIST 2005 databases.

\section{Carbonyl content}

Carbonyl content was determined using the 2,4-dinitrophenylhydrazine (DNPH) method following the procedure of Zhang et al. [2018]. About 2 g of samples were dispersed and diluted to $4 \mathrm{mg} / \mathrm{mL}$ using a buffer containing $0.6 \mathrm{M} \mathrm{NaCl}, 20 \mathrm{mM}$ sodium phosphate buffer, and $8 \mathrm{M}$ urea (pH 7.5), then a $2 \mathrm{~mL}$ diluent was used for the measurement of the carbonyl content. The absorbance was measured at $370 \mathrm{~nm}$ and the carbonyl content was expressed as nmol/mg protein with a molar extinction coefficient of 22,000 $\mathrm{M}^{-1} \mathrm{~cm}^{-1}$.

\section{Total thiols}

Diluent solutions prepared for the measurement of carbonyls were used for the total thiols analysis using the method of Benjakul et al. [1997] with some modification by Zhou et al. [2018]. Diluent solution of $1 \mathrm{~mL}$ was mixed with $9 \mathrm{~mL}$ buffer containing $0.6 \mathrm{M} \mathrm{NaCl}, 20 \mathrm{mM}$ sodium phosphate buffer, $8 \mathrm{M}$ urea $(\mathrm{pH} 7.5)$, and $1 \mathrm{~mL}$ reagent $(0.1 \%$ DTNB in $0.2 \mathrm{M}$ Tris$\mathrm{HCl}$ buffer, $\mathrm{pH}$ 8.0). Samples were kept in the dark at $40^{\circ} \mathrm{C}$ for $25 \mathrm{~min}$ and then measured at $412 \mathrm{~nm}$, and the total thiol content was calculated using a molar extinction coefficient of $13600 \mathrm{M}^{-1} \mathrm{~cm}^{-1}$. The results are expressed as nmol/mg protein.

\section{SDS-PAGE}

The protein extract from the carbonyl determination was used for SDS-PAGE. Samples were diluted to $1 \mathrm{mg} / \mathrm{mL}$ using $2 \times$ SDS-PAGE sample buffer $(0.5 \mathrm{M}$ Tris- $\mathrm{HCl}(\mathrm{pH} 6.8)$, $20 \%$ glycerol, $4 \%$ SDS, and $0.04 \%$ bromophenol blue) with or without $5 \% \beta$-mercaptoethanol ( $\beta$-ME), and $10 \mu \mathrm{L}$ of protein sample were used in electrophoresis with $4 \%$ stacking gel and $8 \%$ resolving gel. Then, the gels were stained in a $0.1 \%$ $(w / v)$ Coomassie Brilliant Blue R-250 solution for $3 \mathrm{~h}$ and destained with a methanol-acetic acid solution (5\% methanol and $7.5 \%$ acetic acid, $v / v$ ) until the bands were clear for around two days.

\section{Differential scanning calorimetry}

Raw and steamed samples from the dorsal part $(\sim 10$ $15 \mathrm{mg}$ ) were weighed and hermetically sealed into aluminum pans, thermograms were obtained using the DSC (214 Polyma, Netzsch-Gerätebau GmbH, Selb, Germany). Samples were first equilibrated at $25^{\circ} \mathrm{C}$ for $5 \mathrm{~min}$, and then heated to $100^{\circ} \mathrm{C}$ at the rate of $10^{\circ} \mathrm{C} / \mathrm{min}$, a sealed empty pan was used as the reference. The denaturation temperatures and enthalpies were analyzed using Proteus software (Netzsch-Gerätebau $\mathrm{GmbH}$ ), and results from 35 to $90^{\circ} \mathrm{C}$ are shown.

\section{Protein solubility}

The extraction of water-soluble and salt-soluble protein components was carried out as described by Visessanguan et al. [2004]. Then, the concentration of the water-soluble fraction, salt-soluble fraction, and total protein was determined using the BCA protein assay kit, and the results are expressed as a percentage of the water-soluble and salt-soluble fraction in the total protein, respectively.

\section{In vitro digestibility}

Both the raw and steam-cooked samples were minced finely using an electric mincer (JYL-C51V, Joyoung Co., Ltd., Jinan, Shandong, China) and then digested under simulated gastrointestinal conditions according to the method of Minekus et al. [2014]. Samples were collected at the end of the gastric phase and intestinal phase for further analysis.

Particle size distribution of samples at different digestive phases (pre-digestive, gastric, and intestinal phases) were analyzed using a Microtrac S3500 (Microtrac Inc., Montgomeryville, PA, USA). Briefly, samples were homogenized using an Ultra Turrax homogenizer (T10, IKA-Werke) at 21,200 rpm for $1 \mathrm{~min}$ and $1 \mathrm{~mL}$ of dispersed solutions $(2 \mathrm{mg} / \mathrm{mL})$ were used for measurement. The refractive index was set to 1.46 and particles were considered as non-spherical. The volume-weighed mean diameter $\mathrm{D}_{4,3}\left(\mathrm{D}_{4,3}=\Sigma \mathrm{n}_{\mathrm{i}} \mathrm{d}_{\mathrm{i}}^{4} / \Sigma \mathrm{n}_{\mathrm{i}} \mathrm{d}_{\mathrm{i}}^{3}\right)$ was recorded to describe the mean particle size.

Furthermore, an inverted fluorescence microscope (Eclipse Ti-U, Nikon Corp., Tokyo, Japan) was used to observe the microstructure changes of fish protein at different digestive phases. Samples were stained with $0.32 \mathrm{mg} / \mathrm{mL}$ fluorescein isothiocyanate (FITC) and kept in the dark for 
TABLE 1. Some physicochemical properties of the raw and steamed muscle samples with different core temperatures of large-mouth bass.

\begin{tabular}{|c|c|c|c|c|c|c|c|c|}
\hline \multirow{2}{*}{\multicolumn{2}{|c|}{ Indexes }} & \multicolumn{6}{|c|}{ Core temperature } & \multirow{2}{*}{$p$ value } \\
\hline & & Control $\left(\sim 25^{\circ} \mathrm{C}\right)$ & $45^{\circ} \mathrm{C}$ & $55^{\circ} \mathrm{C}$ & $65^{\circ} \mathrm{C}$ & $75^{\circ} \mathrm{C}$ & $85^{\circ} \mathrm{C}$ & \\
\hline \multicolumn{2}{|c|}{ Cooking loss (\%) } & - & $5.0 \pm 0.6^{\mathrm{d}}$ & $6.7 \pm 0.6^{\mathrm{c}}$ & $8.4 \pm 0.4^{\mathrm{b}}$ & $9.9 \pm 1.3^{\mathrm{ab}}$ & $11.1 \pm 1.2^{\mathrm{a}}$ & $<0.001^{*}$ \\
\hline \multicolumn{2}{|l|}{$\mathrm{pH}$} & $7.20 \pm 0.09^{\mathrm{a}}$ & $7.18 \pm 0.14^{\mathrm{a}}$ & $7.26 \pm 0.04^{\mathrm{a}}$ & $7.13 \pm 0.04^{\mathrm{a}}$ & $7.06 \pm 0.16^{\mathrm{a}}$ & $7.13 \pm 0.20^{\mathrm{a}}$ & 0.513 \\
\hline \multicolumn{2}{|c|}{$\begin{array}{l}\text { Peroxide value } \\
\text { (meq peroxide/kg dry weight) }\end{array}$} & $0.9 \pm 0.2^{\mathrm{c}}$ & $1.3 \pm 0.3^{\mathrm{c}}$ & $1.2 \pm 0.2^{\mathrm{c}}$ & $1.9 \pm 0.1^{\mathrm{b}}$ & $3.3 \pm 0.6^{\mathrm{a}}$ & $2.4 \pm 0.2^{\mathrm{b}}$ & $<0.001$ \\
\hline \multicolumn{2}{|c|}{$\begin{array}{l}\text { TBARS } \\
\text { (mg MDA/kg dry weight) }\end{array}$} & $1.0 \pm 0.1^{\mathrm{c}}$ & $3.8 \pm 1.4^{\mathrm{b}}$ & $4.1 \pm 0.3^{b}$ & $5.0 \pm 0.4^{\mathrm{b}}$ & $5.4 \pm 0.5^{\mathrm{b}}$ & $8.9 \pm 1.4^{\mathrm{a}}$ & $<0.001$ \\
\hline \multicolumn{2}{|c|}{ Carbonyls (nmol/mg protein) } & $3.0 \pm 0.8^{\mathrm{b}}$ & $4.2 \pm 1.1^{\mathrm{ab}}$ & $5.4 \pm 1.3^{\mathrm{a}}$ & $5.2 \pm 1.0^{\mathrm{ab}}$ & $6.2 \pm 1.8^{\mathrm{a}}$ & $5.9 \pm 1.0^{\mathrm{a}}$ & 0.057 \\
\hline \multicolumn{2}{|c|}{ Total thiols (nmol/mg protein) } & $85 \pm 5^{\mathrm{a}}$ & $70 \pm 3^{b}$ & $71 \pm 8^{b}$ & $69 \pm 3^{\mathrm{b}}$ & $63 \pm 2^{\mathrm{bc}}$ & $61 \pm 4^{c}$ & $<0.001$ \\
\hline \multicolumn{2}{|c|}{ Water-soluble protein (\%) } & $5.36 \pm 0.17^{\mathrm{a}}$ & $2.17 \pm 0.06^{\mathrm{b}}$ & $1.46 \pm 0.11^{\mathrm{c}}$ & $1.51 \pm 0.12^{c}$ & $1.41 \pm 0.04^{\mathrm{c}}$ & $1.36 \pm 0.07^{c}$ & $<0.001$ \\
\hline \multicolumn{2}{|c|}{ Salt-soluble protein $(\%)$} & $9.90 \pm 0.84^{\mathrm{a}}$ & $0.83 \pm 0.03^{\mathrm{b}}$ & $0.65 \pm 0.16^{\mathrm{b}}$ & $0.50 \pm 0.06^{\mathrm{b}}$ & $0.59 \pm 0.02^{\mathrm{b}}$ & $0.57 \pm 0.04^{\mathrm{b}}$ & $<0.001$ \\
\hline \multirow{3}{*}{$\mathrm{D}_{4,3}(\mu \mathrm{m})$} & Pre-digestive phase & $120 \pm 20^{c}$ & $280 \pm 20^{\mathrm{b}}$ & $370 \pm 50^{\mathrm{a}}$ & $350 \pm 60^{\mathrm{ab}}$ & $360 \pm 60^{\mathrm{ab}}$ & $350 \pm 20^{\mathrm{ab}}$ & $<0.001$ \\
\hline & Gastric phase & $80 \pm 10^{c}$ & $110 \pm 10^{\mathrm{b}}$ & $111 \pm 8^{\mathrm{b}}$ & $120 \pm 10^{\mathrm{b}}$ & $150 \pm 10^{\mathrm{a}}$ & $150 \pm 20^{\mathrm{a}}$ & $<0.001$ \\
\hline & Intestinal phase & $33 \pm 4^{b}$ & $60 \pm 10^{\mathrm{a}}$ & $80 \pm 6^{a}$ & $72 \pm 7^{\mathrm{a}}$ & $70 \pm 20^{\mathrm{a}}$ & $69 \pm 8^{a}$ & $<0.001$ \\
\hline
\end{tabular}

Mean values denoted with different letters in superscripts in the same row are statistically significantly different $(p<0.05)$. ${ }^{*}$ The analysis of significance was done in the steamed groups from $45^{\circ} \mathrm{C}$ to $85^{\circ} \mathrm{C}$.

20 min. Each sample was observed using a $20 \times$ magnification objective and analyzed using Nikon NIS-Elements BR software (Nikon Corp., Tokyo, Japan).

\section{Microbiological analysis}

For the microbiological analysis, the fish sample $(5.00 \mathrm{~g})$ was first mixed with sterile $45 \mathrm{~mL}$ of $0.85 \% \mathrm{NaCl}$ solution and then homogenized using a blender (SCIENTZ-09, Ningbo Scientz Biotechnology Co., Ltd., Ningbo, Zhejiang, China) for $2 \mathrm{~min}$ at room temperature. The aerobic count was measured using the $3 \mathrm{M}$ Aerobic Count Plate (3M Microbiology, St. Paul, MN, USA), and total coliforms and generic E. coli were determined using the $3 \mathrm{M}$ Coliform/E. coli Count Plates (3M Microbiology, St. Paul, MN, USA). One milliliter of each diluted solution $\left(10^{-1}\right.$ through $\left.10^{-3}\right)$ was plated in triplicate, the aerobic count plates were incubated at $30^{\circ} \mathrm{C}$ for $72 \mathrm{~h}$ following the ISO Method 4833:2003, and coliform/ E. coli count plates were incubated at $35^{\circ} \mathrm{C}$ for $24 \mathrm{~h}$ following the AOAC Official Method 998.08. The results are expressed as $\log \mathrm{CFU} / \mathrm{g}$.

\section{Statistical analysis}

Measurements were all done in triplicates. Results were analyzed using the Statistical Package for the Social Sciences Statistics 20 software (International Business Machines Corp., Chicago, IL, USA) with the one-way analysis of variance (ANOVA). Significant differences were identified using the Duncan's test at an $\alpha$ level of 0.05 . The partial least squares (PLS) analysis between fatty acids and the related lipid oxidation and degradation indicators (PV, TBARS and volatile compounds) was performed using XL STAT 2015 software (Addinsoft Inc., NY, USA).

\section{RESULTS AND DISCUSSION}

\section{Cooking loss and pH}

Endpoint temperature of steam cooking showed a significant impact on the cooking loss of large-mouth bass (Table 1). The value increased significantly from $5.0 \%$ at $45^{\circ} \mathrm{C}$ to $8.4 \%$ at $65^{\circ} \mathrm{C}(p<0.05)$, while the difference was not significant between $65^{\circ} \mathrm{C}$ and $75^{\circ} \mathrm{C}(p>0.05)$, and the cooking loss reached the maximum of $11.1 \%$ at the temperature of $85^{\circ} \mathrm{C}$. This could be related to the structural changes of fish meat. Li et al. [2013] observed the transverse shrinkage of muscle fibers in duck breast meat below $50^{\circ} \mathrm{C}$, when the temperature was above $60^{\circ} \mathrm{C}$, the fibers and connective tissue shrank longitudinally with the significant decrease in sarcomere length. The shrinkage pressure accelerated the extrusion of water and the increase of cooking loss, which could further influence the juiciness and eating quality of fish meat. But steaming did not influence the $\mathrm{pH}(p>0.05)$, the control and steamed samples all had $\mathrm{pH}$ values slightly above 7 (Table 1).

\section{Lipid oxidation}

Lipid oxidation is an important reaction that occurs during fish cooking. Such oxidation is believed to proceed via a free radical chain reaction depending on the oxidative environment and muscle characteristics [Lund et al., 2011]. PV can be used to show the level of primary lipid oxidation products during steaming. PV increased significantly with the increase of core temperature $(p<0.001)$ and reached the maximum at $75^{\circ} \mathrm{C}$ (3.3 meq peroxide $/ \mathrm{kg}$ dry weight), and then decreased significantly at $85^{\circ} \mathrm{C}(2.4$ meq peroxide $/ \mathrm{kg}$ dry weight) as shown in Table $1(p<0.05)$. The degradation of primary oxidation products promoted the generation of secondary products, which could be estimated using TBARS, and the highest value of $8.9 \mathrm{mg}$ $\mathrm{MDA} / \mathrm{kg}$ dry weight was reached at $85^{\circ} \mathrm{C}$. The study of Dong 
TABLE 2. The fatty acid composition (\% of total fatty acids) of the raw (control) and steamed large-mouth bass with different core temperatures.

\begin{tabular}{|c|c|c|c|c|c|c|}
\hline Fatty acid & Control $\left(\sim 25^{\circ} \mathrm{C}\right)$ & $45^{\circ} \mathrm{C}$ & $55^{\circ} \mathrm{C}$ & $65^{\circ} \mathrm{C}$ & $75^{\circ} \mathrm{C}$ & $85^{\circ} \mathrm{C}$ \\
\hline C14:0 & $1.99 \pm 0.05^{\mathrm{c}}$ & $2.99 \pm 0.30^{b}$ & $2.95 \pm 0.26^{\mathrm{b}}$ & $3.09 \pm 0.27^{\mathrm{b}}$ & $2.77 \pm 0.54^{b}$ & $3.65 \pm 0.12^{\mathrm{a}}$ \\
\hline C15:0 & $0.28 \pm 0.01^{\mathrm{c}}$ & $0.47 \pm 0.03^{b}$ & $0.44 \pm 0.02^{\mathrm{b}}$ & $0.46 \pm 0.06^{\mathrm{b}}$ & $0.44 \pm 0.06^{\mathrm{b}}$ & $0.64 \pm 0.03^{\mathrm{a}}$ \\
\hline C16:0 & $17.7 \pm 0.3^{\mathrm{b}}$ & $21.6 \pm 0.5^{\mathrm{a}}$ & $21.5 \pm 0.6^{\mathrm{a}}$ & $23.5 \pm 2.7^{\mathrm{a}}$ & $22.2 \pm 1.3^{\mathrm{a}}$ & $23.9 \pm 2.7^{\mathrm{a}}$ \\
\hline $\mathrm{C} 17: 0$ & $0.25 \pm 0.01^{\mathrm{c}}$ & $0.41 \pm 0.01^{\mathrm{b}}$ & $0.41 \pm 0.01^{\mathrm{b}}$ & $0.41 \pm 0.03^{\mathrm{b}}$ & $0.38 \pm 0.08^{b}$ & $0.58 \pm 0.00^{\mathrm{a}}$ \\
\hline C18:0 & $2.87 \pm 0.13^{\mathrm{c}}$ & $3.21 \pm 0.10^{\mathrm{bc}}$ & $3.39 \pm 0.26^{\mathrm{abc}}$ & $3.87 \pm 0.57^{\mathrm{a}}$ & $3.67 \pm 0.22^{\mathrm{ab}}$ & $3.47 \pm 0.08^{\mathrm{ab}}$ \\
\hline C20:0 & $0.22 \pm 0.02^{\mathrm{b}}$ & $0.21 \pm 0.02^{\mathrm{b}}$ & $0.20 \pm 0.02^{\mathrm{b}}$ & $0.23 \pm 0.03^{\mathrm{b}}$ & $0.23 \pm 0.05^{b}$ & $0.32 \pm 0.03^{\mathrm{a}}$ \\
\hline C22:0 & $0.19 \pm 0.01^{\mathrm{ab}}$ & $0.14 \pm 0.01^{\mathrm{b}}$ & $0.14 \pm 0.02^{\mathrm{b}}$ & $0.22 \pm 0.05^{\mathrm{a}}$ & $0.19 \pm 0.02^{\mathrm{ab}}$ & $0.15 \pm 0.07^{\mathrm{ab}}$ \\
\hline$\sum$ SFA & $23.5 \pm 0.4^{c}$ & $29.0 \pm 0.3^{b}$ & $29.1 \pm 0.6^{b}$ & $31.8 \pm 3.1^{\mathrm{ab}}$ & $29.9 \pm 1.1^{\mathrm{ab}}$ & $32.7 \pm 2.5^{\mathrm{a}}$ \\
\hline $\mathrm{C} 16: 1 n-7$ & $4.8 \pm 0.5^{\mathrm{b}}$ & $8.1 \pm 0.2^{\mathrm{a}}$ & $8.3 \pm 0.9^{a}$ & $7.2 \pm 0.8^{\mathrm{a}}$ & $7.2 \pm 0.9^{\mathrm{a}}$ & $7.0 \pm 0.4^{\mathrm{a}}$ \\
\hline $\mathrm{C} 17: 1$ & $0.32 \pm 0.02^{\mathrm{d}}$ & $0.60 \pm 0.01^{\mathrm{b}}$ & $0.61 \pm 0.04^{\mathrm{b}}$ & $0.61 \pm 0.04^{\mathrm{b}}$ & $0.53 \pm 0.07^{c}$ & $0.69 \pm 0.02^{\mathrm{a}}$ \\
\hline $\mathrm{C} 18: 1 n-9$ & $27 \pm 1^{a}$ & $26 \pm 2^{\mathrm{ab}}$ & $28 \pm 1^{\mathrm{a}}$ & $26 \pm 3^{a}$ & $27 \pm 2^{\mathrm{a}}$ & $22 \pm 2^{b}$ \\
\hline $\mathrm{C} 20: 1 n-9$ & $1.61 \pm 0.05^{\mathrm{b}}$ & $2.22 \pm 0.27^{\mathrm{a}}$ & $1.78 \pm 0.02^{\mathrm{ab}}$ & $2.26 \pm 0.42^{\mathrm{a}}$ & $2.17 \pm 0.34^{\mathrm{a}}$ & $2.21 \pm 0.29^{\mathrm{a}}$ \\
\hline C22:1n-9 & $0.61 \pm 0.02^{\mathrm{d}}$ & $1.39 \pm 0.09^{\mathrm{ab}}$ & $1.16 \pm 0.16^{\mathrm{bc}}$ & $1.63 \pm 0.17^{\mathrm{a}}$ & $1.41 \pm 0.26^{\mathrm{ab}}$ & $0.97 \pm 0.19^{c}$ \\
\hline$\sum$ MUFA & $34 \pm 2^{b}$ & $38 \pm 1^{a}$ & $40 \pm 1^{\mathrm{a}}$ & $38 \pm 2^{a}$ & $38 \pm 2^{a}$ & $33 \pm 2^{\mathrm{b}}$ \\
\hline C18:2n-6 & $27.62 \pm 1.20^{\mathrm{a}}$ & $4.63 \pm 0.48^{b}$ & $5.07 \pm 0.40^{\mathrm{b}}$ & $4.21 \pm 0.55^{\mathrm{b}}$ & $5.16 \pm 0.45^{b}$ & $1.79 \pm 0.04^{c}$ \\
\hline C18:3n-3 & $2.47 \pm 0.11^{\mathrm{a}}$ & $0.94 \pm 0.06^{\mathrm{b}}$ & $0.92 \pm 0.04^{b}$ & $0.89 \pm 0.04^{\mathrm{b}}$ & $0.96 \pm 0.16^{\mathrm{b}}$ & $0.81 \pm 0.00^{\mathrm{b}}$ \\
\hline C18:3n-6 & $0.14 \pm 0.01^{\mathrm{b}}$ & $0.28 \pm 0.01^{\mathrm{a}}$ & $0.29 \pm 0.03^{\mathrm{a}}$ & $0.28 \pm 0.02^{\mathrm{a}}$ & $0.19 \pm 0.06^{b}$ & $0.30 \pm 0.03^{\mathrm{a}}$ \\
\hline C20:2n-6 & $0.56 \pm 0.04^{\mathrm{a}}$ & $0.36 \pm 0.02^{\mathrm{b}}$ & $0.35 \pm 0.01^{\mathrm{b}}$ & $0.33 \pm 0.03^{\mathrm{b}}$ & $0.37 \pm 0.03^{b}$ & $0.32 \pm 0.02^{\mathrm{b}}$ \\
\hline $\mathrm{C} 20: 3 n-3$ & $0.19 \pm 0.00^{\mathrm{a}}$ & $0.15 \pm 0.01^{\mathrm{b}}$ & $0.14 \pm 0.01^{\mathrm{b}}$ & $0.16 \pm 0.03^{b}$ & $0.15 \pm 0.03^{b}$ & $0.14 \pm 0.00^{\mathrm{b}}$ \\
\hline $\mathrm{C} 20: 3 n-6$ & $0.15 \pm 0.03^{b}$ & $0.24 \pm 0.01^{\mathrm{a}}$ & $0.24 \pm 0.01^{\mathrm{a}}$ & $0.23 \pm 0.03^{\mathrm{a}}$ & $0.22 \pm 0.04^{\mathrm{a}}$ & $0.16 \pm 0.01^{\mathrm{b}}$ \\
\hline $\mathrm{C} 20: 4 n-6$ & $0.37 \pm 0.04^{\mathrm{d}}$ & $1.12 \pm 0.06^{\mathrm{c}}$ & $1.11 \pm 0.11^{\mathrm{c}}$ & $1.17 \pm 0.11^{\mathrm{c}}$ & $3.35 \pm 0.36^{\mathrm{b}}$ & $5.08 \pm 0.25^{\mathrm{a}}$ \\
\hline $\mathrm{C} 20: 5 n-3$ & $1.24 \pm 0.09^{\mathrm{d}}$ & $3.38 \pm 0.07^{b}$ & $3.00 \pm 0.28^{c}$ & $3.72 \pm 0.14^{\mathrm{a}}$ & $0.77 \pm 0.06^{\mathrm{e}}$ & $0.80 \pm 0.02^{\mathrm{e}}$ \\
\hline $\mathrm{C} 22: 5 n-3$ & $1.52 \pm 0.05^{\mathrm{b}}$ & $3.21 \pm 0.18^{\mathrm{a}}$ & $2.97 \pm 0.16^{\mathrm{a}}$ & $2.82 \pm 0.65^{\mathrm{a}}$ & $3.00 \pm 0.68^{\mathrm{a}}$ & $3.48 \pm 0.94^{\mathrm{a}}$ \\
\hline $\mathrm{C} 22: 6 n-3$ & $7.8 \pm 0.8^{\mathrm{b}}$ & $18.6 \pm 0.4^{\mathrm{a}}$ & $17.3 \pm 1.0^{\mathrm{a}}$ & $16.5 \pm 4.5^{\mathrm{a}}$ & $17.9 \pm 0.5^{\mathrm{a}}$ & $21.1 \pm 3.8^{\mathrm{a}}$ \\
\hline$\sum$ PUFA & $42 \pm 2^{\mathrm{a}}$ & $33 \pm 1^{b}$ & $31 \pm 1^{b}$ & $30 \pm 5^{b}$ & $32 \pm 2^{b}$ & $34 \pm 5^{b}$ \\
\hline
\end{tabular}

Mean values denoted with different letters in superscripts in the same row are statistically significantly different $(p<0.05)$. SFA: saturated fatty acids. PUFA: polyunsaturated fatty acids. MUFA: monounsaturated fatty acids.

et al. [2018] also found the similar results, that is, a higher temperature with prolonged heating time led to an increased MDA content and generated more carbon-centered radicals in scallop adductor muscle. Therefore, in order to avoid the severe lipid oxidation, the core temperature should not exceed $85^{\circ} \mathrm{C}$ during the steam cooking of large-mouth bass.

\section{Fatty acid composition}

In this study, 22 fatty acids were identified in fish lipid. Results are shown in Table 2. According to the changes during steaming, the core temperature had a great influence on fatty acid composition of large-mouth bass. The proportion of saturated fatty acids increased with the increase of core temperature, especially myristic acid (C14:0), pentadecanoic acid (C15:0), and heptadecanoic acid (C17:0). Most of the monounsaturated fatty acids showed an increasing trend during steaming, but the proportion of oleic acid (C18:1n-9) decreased significantly at the core temperature of $85^{\circ} \mathrm{C}$. Four polyunsaturated fatty acids, linoleic acid (C18:2n-6), linolenic acid (C18:3n-3), eicosadienoic acid (C20:2n-6), and 8,11,14-eicosatrienoic acid (C20:3n-3), decreased significantly in proportion during steaming. In general, the composition of fatty acids at the core temperature of $85^{\circ} \mathrm{C}$ is quite different from other steaming temperatures. In the study of Bastías et al. [2017], salmon fillets processed with steaming treatment showed a higher proportion of omega-3 fatty acids, especially DHA, when compared with oven cooking and microwaving methods. The advantage of steaming in retaining the unsaturated fatty acids was also seen in the research of Shi et al. [2019]. Compared with roasting, steaming significantly increased the contents of free EPA, DHA and ARA in tilapia fillets, which might have resulted from the breakdown of triglyceride. Therefore, in order to maintain the nutritious unsaturated fatty acids, steaming method was recommended in fish cooking. 
TABLE 3. The volatile compounds of the raw (control) and steamed large-mouth bass with different core temperatures.

\begin{tabular}{|c|c|c|c|c|c|c|}
\hline \multirow{2}{*}{ Compound } & \multicolumn{6}{|c|}{ Content $(\mu \mathrm{g} / 100 \mathrm{~g})$} \\
\hline & Control $\left(\sim 25^{\circ} \mathrm{C}\right)$ & $45^{\circ} \mathrm{C}$ & $55^{\circ} \mathrm{C}$ & $65^{\circ} \mathrm{C}$ & $75^{\circ} \mathrm{C}$ & $85^{\circ} \mathrm{C}$ \\
\hline \multicolumn{7}{|c|}{ Aldehydes } \\
\hline Hexanal & $170 \pm 20^{\mathrm{d}}$ & $260 \pm 4^{c}$ & $300 \pm 10^{\mathrm{abc}}$ & $270 \pm 20^{\mathrm{bc}}$ & $350 \pm 40^{\mathrm{a}}$ & $320 \pm 50^{\mathrm{ab}}$ \\
\hline Heptanal & $15.2 \pm 2.5^{\mathrm{d}}$ & $21.3 \pm 0.3^{\mathrm{bc}}$ & $22.5 \pm 3.3^{\mathrm{bc}}$ & $18.7 \pm 3.9^{\mathrm{cd}}$ & $31.2 \pm 4.6^{\mathrm{a}}$ & $27.3 \pm 3.5^{\mathrm{ab}}$ \\
\hline (Z)-4-heptenal & $3.9 \pm 0.9^{\mathrm{a}}$ & $3.4 \pm 0.6^{\mathrm{a}}$ & $3.6 \pm 1.5^{\mathrm{a}}$ & $3.8 \pm 0.2^{\mathrm{a}}$ & $4.9 \pm 0.4^{\mathrm{a}}$ & $5.1 \pm 1.3^{\mathrm{a}}$ \\
\hline Octanal & $11 \pm 2^{\mathrm{c}}$ & $14 \pm 2^{\mathrm{bc}}$ & $13 \pm 1^{b c}$ & $12 \pm 3^{\mathrm{bc}}$ & $19 \pm 3^{\mathrm{a}}$ & $17 \pm 4^{\mathrm{ab}}$ \\
\hline Nonanal & $9.1 \pm 1.4^{\mathrm{c}}$ & $13.6 \pm 0.3^{\mathrm{b}}$ & $16.8 \pm 1.6^{\mathrm{ab}}$ & $14.2 \pm 2.8^{\mathrm{b}}$ & $20.0 \pm 2.6^{\mathrm{a}}$ & $17.6 \pm 3.3^{\mathrm{ab}}$ \\
\hline (E)-2-octenal & $1.25 \pm 0.02^{\mathrm{a}}$ & $1.05 \pm 0.11^{\mathrm{ab}}$ & $1.16 \pm 0.21^{\mathrm{ab}}$ & $0.88 \pm 0.21^{\mathrm{ab}}$ & $0.65 \pm 0.57^{\mathrm{b}}$ & $1.00 \pm 0.28^{\mathrm{ab}}$ \\
\hline Decanal & $0.5 \pm 0.7^{\mathrm{a}}$ & $1.0 \pm 1.1^{\mathrm{a}}$ & $1.7 \pm 1.4^{\mathrm{a}}$ & $0.8 \pm 1.0^{\mathrm{a}}$ & $1.2 \pm 1.1^{\mathrm{a}}$ & nd \\
\hline \multicolumn{7}{|c|}{ Ketones } \\
\hline 2,3-Pentanedione & $13 \pm 3^{\mathrm{a}}$ & $12 \pm 1^{\mathrm{a}}$ & $13 \pm 2^{\mathrm{a}}$ & $12 \pm 2^{\mathrm{a}}$ & $8 \pm 8^{\mathrm{a}}$ & $11 \pm 2^{\mathrm{a}}$ \\
\hline 2-Nonanone & $0.6 \pm 0.1^{\mathrm{c}}$ & $1.6 \pm 0.4^{\mathrm{ab}}$ & $2.0 \pm 0.7^{\mathrm{a}}$ & $1.1 \pm 0.4^{\mathrm{bc}}$ & $1.4 \pm 0.3^{\mathrm{ab}}$ & $1.4 \pm 0.3^{\mathrm{ab}}$ \\
\hline \multicolumn{7}{|c|}{ Alcohols } \\
\hline 1-Penten-3-ol & nd & nd & $14 \pm 13^{\mathrm{a}}$ & nd & $23 \pm 2^{a}$ & $15 \pm 13^{\mathrm{a}}$ \\
\hline 1-Pentanol & $6 \pm 1^{\mathrm{c}}$ & $15 \pm 2^{\mathrm{ab}}$ & $19 \pm 2^{\mathrm{a}}$ & $9 \pm 8^{\mathrm{bc}}$ & $15 \pm 1^{\mathrm{ab}}$ & $8 \pm 6^{\mathrm{bc}}$ \\
\hline 1-Hexanol & $3 \pm 0^{c}$ & $70 \pm 40^{\mathrm{ab}}$ & $110 \pm 40^{\mathrm{a}}$ & $50 \pm 30^{\mathrm{bc}}$ & $10 \pm 8^{c}$ & $2 \pm 0^{\mathrm{c}}$ \\
\hline 1-Octen-3-ol & $23 \pm 3^{b}$ & $42 \pm 3^{\mathrm{a}}$ & $47 \pm 9^{a}$ & $39 \pm 6^{\mathrm{a}}$ & $44 \pm 6^{\mathrm{a}}$ & $50 \pm 10^{\mathrm{a}}$ \\
\hline 1-Heptanol & $1 \pm 0^{\mathrm{b}}$ & $19 \pm 10^{\mathrm{a}}$ & $26 \pm 8^{\mathrm{a}}$ & $17 \pm 6^{\mathrm{a}}$ & $15 \pm 6^{\mathrm{a}}$ & $13 \pm 6^{\mathrm{a}}$ \\
\hline 1-Octanol & $2 \pm 1^{\mathrm{c}}$ & $7 \pm 3^{\mathrm{ab}}$ & $9 \pm 3^{\mathrm{a}}$ & $5 \pm 2^{\mathrm{bc}}$ & $4 \pm 0^{\mathrm{bc}}$ & $3 \pm 1^{\mathrm{bc}}$ \\
\hline 1-Nonanol & $1 \pm 1^{\mathrm{a}}$ & $3 \pm 1^{\mathrm{a}}$ & $4 \pm 2^{\mathrm{a}}$ & $5 \pm 6^{\mathrm{a}}$ & nd & nd \\
\hline
\end{tabular}

Mean values denoted with different letters in superscripts in the same row are statistically significantly different $(p<0.05)$. "nd" indicates that the substance has not been detected.

\section{Volatile compounds}

It is known that lipid oxidation plays a key role in the formation of volatile compounds which contribute to the flavor of cooked fish, and the volatile compounds associated with the lipid oxidation in this study are listed in Table 3. Aldehyde, which was high in content and low in threshold, was an important contributor in the formation of fish flavor. With the increase of the core temperature, the content of hexanal, heptanal, octanal, and nonanal significantly increased during steaming especially at $75^{\circ} \mathrm{C}$ and $85^{\circ} \mathrm{C}(p<0.05)$, and at the same time provided the grassy, fatty and fruity flavor to the steamed fish. As for alcohols, the content of 1-octen-3-ol and 1-heptanol increased significantly after steaming $(p<0.05)$, which generally yield fatty and vegetable-like flavors, could help to enrich a cooked fish odor with less fishy smell. While for 1-pentanol, 1-hexanol, and 1-octanol, the contents decreased when the core temperature was above $65^{\circ} \mathrm{C}$. Combined with the sensory analysis in our previous study [Wang et al., 2019], when the core temperature reached $75^{\circ} \mathrm{C}$, the increased formation of volatile compounds significantly improved the odor attribute and the consumer acceptance, while the fishy smell was still obvious at the core temperature of $65^{\circ} \mathrm{C}$ with lower odor and taste score.

Furthermore, correlations between fatty acids and related lipid oxidation and degradation indicators (PV, TBARS and volatile compounds) were analyzed using PLS. The results in Table 1 suggest that contents of the following fatty acids C18:2n-6, C18:3n-3, C20:2n-6, C20:3n-3, and also C18:1n-9 were negatively related with PV and TBARS, and around the PV and TBARS were mainly volatile aldehydes like octanal, heptanal, nonanal, and hexanal, which also showed negative and close correlations with the unsaturated fatty acids mentioned above. Combined with the location of samples in Figure 1, the proportion of unsaturated fatty acids like C18:2n-6 and C18:3n-3 was comparatively high in the raw sample as they were very close to the control in distance and had a major negative loading on t1. While steaming caused the oxidation and degradation of these fatty acids and contributed to the increase of PV and TBARS (Table 1), and the formation of volatile compounds (Table 3 ), as the steamed samples were located quite far from the control. Samples of $45^{\circ} \mathrm{C}$ and $65^{\circ} \mathrm{C}$ had small negative loadings on $\mathrm{t} 1$ and $\mathrm{t} 2$, the sample of $55^{\circ} \mathrm{C}$ was located in the fourth quadrant and mainly the alcohols such as 1-hexanol and 1-octanol were around it. And the lipid oxidation was much severer at higher temperatures of $75^{\circ} \mathrm{C}$ and $85^{\circ} \mathrm{C}$ as they were closer to the indicators of PV and TBARS, and the corresponding aldehydes also increased significantly at these temperatures (Table 3 ). 
Based on the literature and findings from this study, an oxidative degradation pathway of oleic acid, which had a high proportion in fatty acids of large-mouth bass, was proposed as an example (Figure 2). During steaming, heme irons together with heating and oxygen initiated lipid oxidation and generated oleic peroxides. The oleic peroxides were not stable and the C-8, C-9, C-10, and C-11 might undergo scission to produce a series of aldehydes and alcohols, and they generally increased with increased temperature. Among these aldehydes and alcohols, hexanal and 1-hexanol were the dominant ones. At higher core temperatures, 1-hexanol decreased possibly due to further reactions. Similar changes can also occur in linoleic and linolenic acids, and the formation of volatile compounds improved the flavor of fish during steaming [Schaich et al., 2013].

\section{Protein oxidation}

Oxidative stress can transfer from lipids to proteins. And protein oxidation in fish can be characterized by the formation of carbonylation and the loss of thiol groups (Table 1). In our study, the temperature does play an important role in the oxidation of proteins. The content of carbonyls increased during the steaming process, which doubled at $75^{\circ} \mathrm{C}$ and $85^{\circ} \mathrm{C}(6.2$ and $5.9 \mathrm{nmol} / \mathrm{mg}$ protein, respectively) compared to the raw sample $(3.0 \mathrm{nmol} / \mathrm{mg}$ protein $)$. While the total thiols decreased significantly and reached a minimum of $61 \mathrm{nmol} / \mathrm{mg}$ protein at the core temperature of $85^{\circ} \mathrm{C}$.
Apart from the changes in carbonyl groups and free thiols, the formation of Schiff bases was also found in sturgeon fillets prepared with different cooking methods [Hu et al., 2017]. Combined with the proteomic analysis, heating induced the modification of aromatic residues such as tyrosine and tryptophan, and the formation of advanced glycation end-products, which was much severer in the roasted than in the steamed samples. Thus, the appropriate temperature and time should be chosen in fish cooking to avoid the excessive oxidation and the loss of protein nutritional value.

\section{SDS-PAGE}

From the results of SDS-PAGE shown in Figure 3, there was no significant difference between the electrophoretic bands of different steam-treated groups, with the addition of $\beta$-ME (Figure 3a). While under the non-reducing condition, the intensity of bands such as the myosin heavy chain (MHC, $220 \mathrm{kDa}$ ), actin $(43 \mathrm{kDa})$, and the bands between $75-100 \mathrm{kDa}$ decreased significantly with the increase of the core temperatures (Figure $3 b$ ). In addition, the amount of proteins that could not enter the gel also increased compared with the reducing groups. Combined with the significant decrease of total thiols (Table 1) especially at $85^{\circ} \mathrm{C}$, it could be concluded that the formation of disulfide bridges through free thiols might be the main cause of protein aggregation. However, there were still some proteins at the top of the stacking gel with the reducing conditions (Figure 3a), which suggested that covalent bonds other than

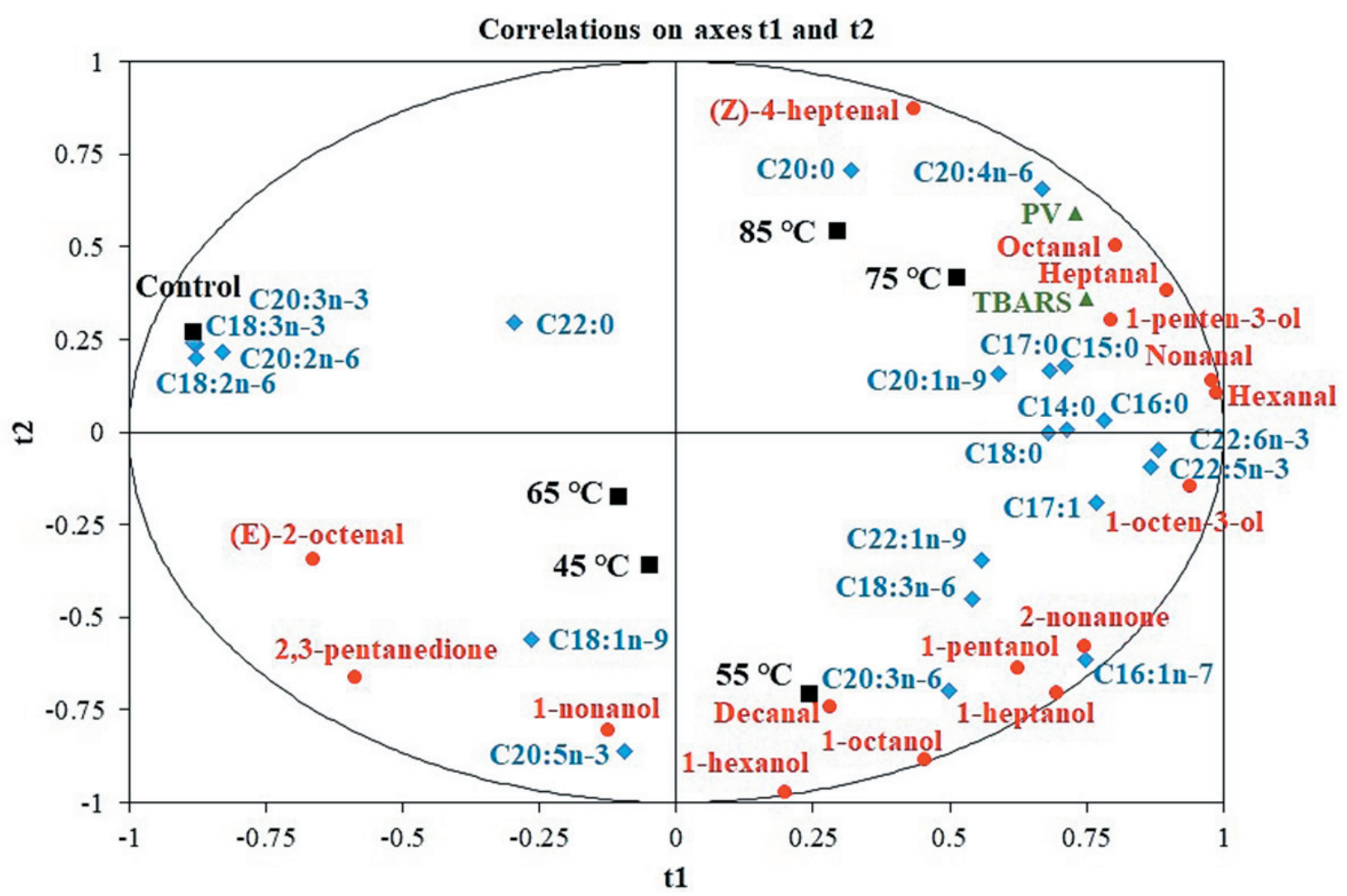

FIGURE 1. Partial least squares (PLS) analysis for the associations of fatty acids (blue) and related lipid oxidation and degradation indicators (PV, TBARS in green and volatile compounds in red) in the raw (control) and steamed large-mouth bass with different core temperatures (black). 


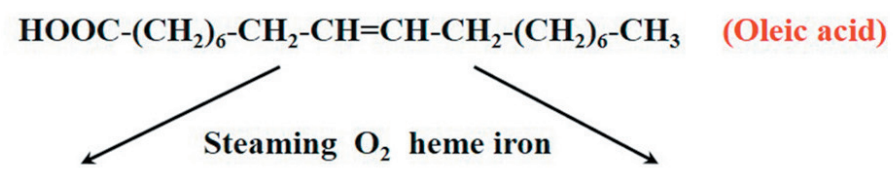

8-O.

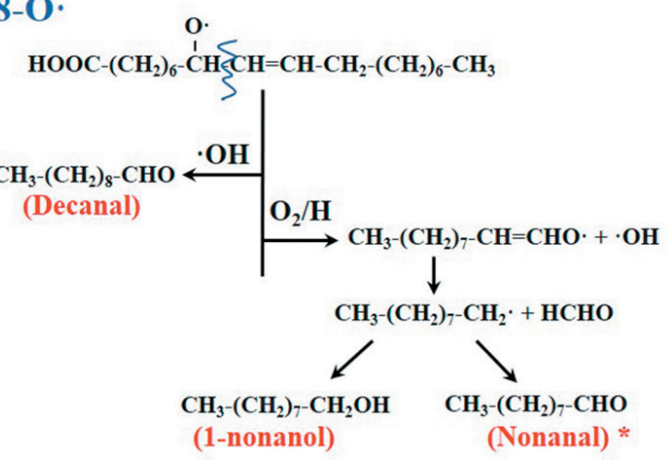

10-O.

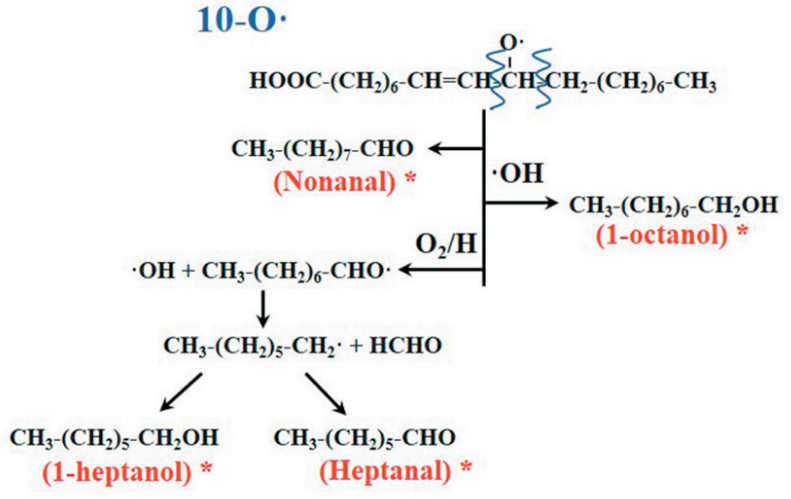

9-O.

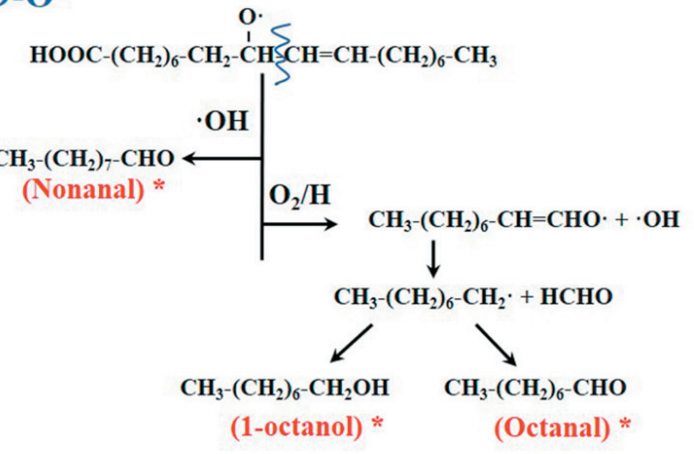

11-O-

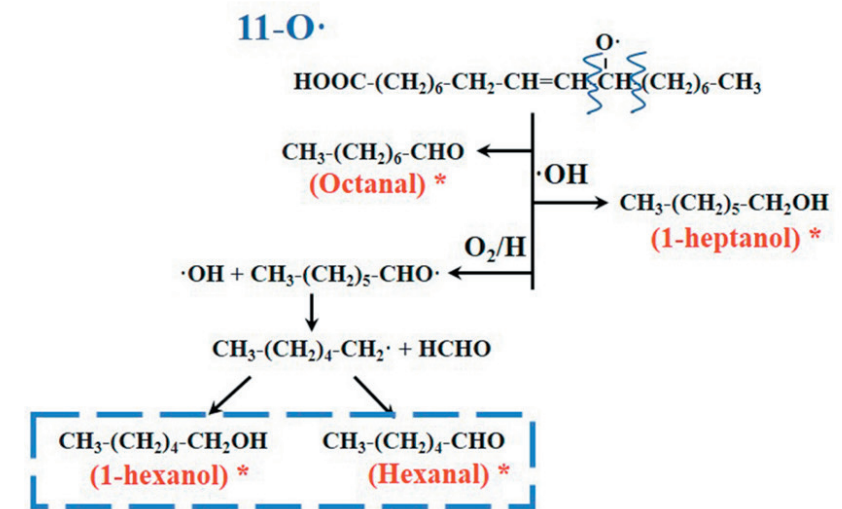

FIGURE 2. Proposed oxidative degradation pathway of oleic acid, modified from Schaich et al. [2013]. *Represents the content of this product generally increased after steaming. The dominant products as identified by GC-MS were hexanal and 1-hexanol.
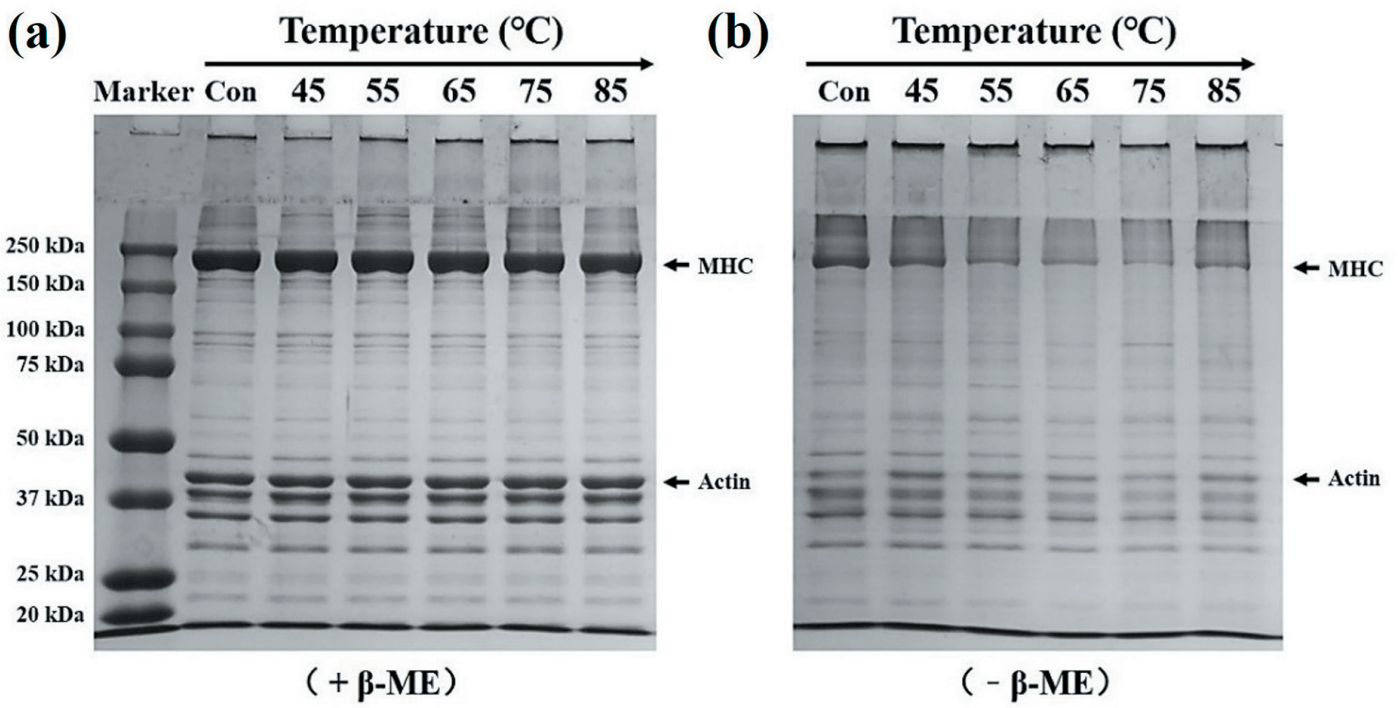

FIGURE 3. SDS-PAGE patterns of the raw (control) and steamed large-mouth bass with different core temperatures. Samples were prepared with $(+\beta-\mathrm{ME}, \mathrm{a})$ or without $(-\beta-\mathrm{ME}, \mathrm{b}) 5 \% \beta$-mercaptoethanol. Positions of the MW marker, myosin heavy chain (MHC), and actin were marked. 
disulfides also participated in the physicochemical reactions of protein during steaming. Such cross-linking and aggregation could further impact the solubility of proteins, and the conformational change of proteins might to some extent influence the digestibility of fish meat.

\section{Differential scanning calorimetry and protein solubility}

The thermal properties of proteins in fish meat were measured using DSC. Figure 4 shows that before steaming, the raw sample contained two major endothermic peaks. Based on the previous study of Korzeniowska et al. [2013], these two thermal transitions of the control could be attributed as follows: Peak 1 might correspond to the myosin and sarcoplasmic protein $\left(47-60^{\circ} \mathrm{C}\right)$, and peak 2 might be assigned to actin $\left(67-77^{\circ} \mathrm{C}\right)$. The denaturation enthalpy values of peak 1 and peak 2 in the raw sample were 1.21 and $0.43 \mathrm{~J} / \mathrm{g}$, respectively. And the disappearance of peak 1 was pronounced when the core temperature reached $55^{\circ} \mathrm{C}$, indicating the denaturation of related proteins. Higher temperatures led to the complete denaturation of proteins and no peak was detectable when the core temperature increased to $65^{\circ} \mathrm{C}$. Protein denaturation could also be seen in changes of the protein solubility (Table 1), with the significant decreased solubility of both the water-soluble and salt-soluble proteins when applied with steaming $(p<0.001)$, and the amount of water-soluble proteins was much less when the core temperature was above $55^{\circ} \mathrm{C}$.

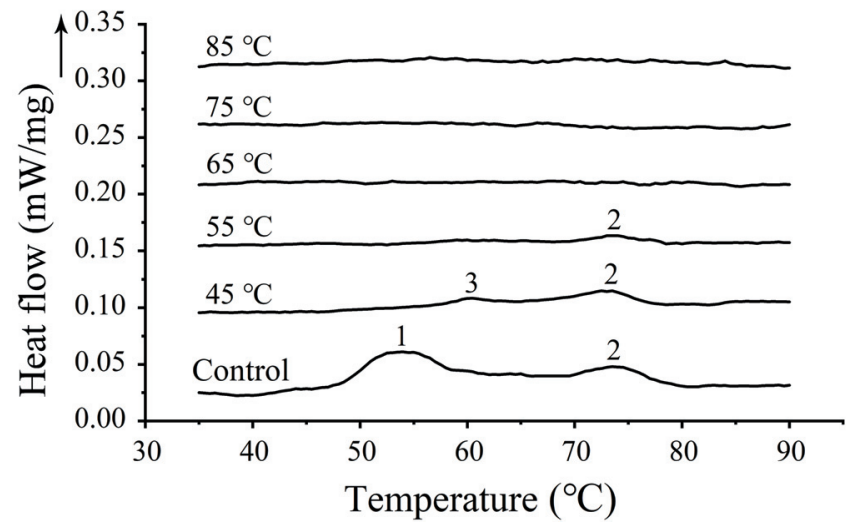

FIGURE 4. DSC thermograms of the raw (control) and steamed large-mouth bass with different core temperatures. Peak 1: myosin and sarcoplasmic protein; Peak 2: actin; Peak 3: sarcoplasmic protein. The arrow pointing up indicated the endothermic reaction.
The protein oxidation and aggregation mainly through disulfide bonds (Figure 3) reduced the binding ability between the protein and water, and thus caused the decreased content of soluble proteins, and the loss of water from the myofibrillar matrix as shown in the result of cooking loss (Table 1).

\section{In vitro digestibility}

The oxidation and aggregation of proteins would further affect their gastrointestinal digestion, and in this study the particle size distribution after different digestive phases was used to reflect the aggregation and in vitro digestibility of fish protein. Steaming caused a significant increase in particle size $(p<0.001)$ compared with the raw sample (Table 1), which was in accordance with the increased aggregation of proteins as indicated by the SDS-PAGE (Figure 3). At the gastric phase, the particle size increased significantly with the increase of core temperature $(p<0.05)$, especially above $75^{\circ} \mathrm{C}$, indicating that samples were not digested so well when compared with the raw sample. But no difference was found after intestinal digestion $(p>0.05)$. Size changes of the fish meat homogenates during in vitro digestion were supported by the micrographs (Figure 5). Fish protein aggregated into larger molecules when the core temperature was above $55^{\circ} \mathrm{C}$. After digestion, proteins were hydrolyzed by enzymes and the fluorescence intensity of the background increased, while steaming groups still had the large protein not digested fully.

As shown in the study of Wen et al. [2015], compared with the core temperatures between $60^{\circ} \mathrm{C}$ and $70^{\circ} \mathrm{C}$, a higher core temperature of $100^{\circ} \mathrm{C}$ resulted in a significant decrease in the digestibility of pork meat and changed the peptide composition. Some studies suggested that moderate oxidation and conformational changes of protein might improve its digestibility. However, further oxidation and aggregation of sarcoplasmic and myofibrillar proteins reduced the interaction sites between digestive enzymes and proteins, thus resulting in a decline in the overall digestibility of food [Bax et al., 2012; Sun et al., 2011]. Furthermore, the oxidative modification of proteins and formed potentially toxic products, such as $\alpha$-aminoadipic acid and HNE-bound protein, could have a harmful implication on human health during the food digestion and adsorption.

\section{Microbiological analysis}

From the aspect of food safety, the aerobic count, total coliforms, and generic $E$. coli were determined in this study. The aerobic colony count in ready-to-eat fish food with sat-

TABLE 4. Counts of indicator microorganisms (aerobic count, total coliforms and generic E. coli) in raw (control) and steamed large-mouth bass with different core temperatures.

\begin{tabular}{l|c|c|c|c|c|c}
\hline \multirow{2}{*}{ Microorganisms } & \multicolumn{7}{c}{ Counts $(\log \mathrm{CFU} / \mathrm{g})$} & \multicolumn{2}{c}{$75^{\circ} \mathrm{C}$} & $85^{\circ} \mathrm{C}$ \\
\cline { 2 - 7 } & Control $\left(\sim 25^{\circ} \mathrm{C}\right)$ & $45^{\circ} \mathrm{C}$ & $55^{\circ} \mathrm{C}$ & $65^{\circ} \mathrm{C}$ & $1.2 \pm 0.7^{\mathrm{c}}$ & $1.3 \pm 0.5^{\mathrm{c}}$ \\
\hline Aerobic count & $3.2 \pm 0.1^{\mathrm{a}}$ & $3.0 \pm 0.2^{\mathrm{a}}$ & $2.6 \pm 0.1^{\mathrm{ab}}$ & $2.0 \pm 0.5^{\mathrm{b}}$ & nd & nd \\
Total coliforms & $1.2 \pm 0.3$ & nd & nd & nd & nd & nd \\
Generic $E$. coli & nd & nd & nd & nd & & nd
\end{tabular}

Mean values denoted with different letters in superscripts in the same row are statistically significantly different $(p<0.05)$. "nd" means not detected. 


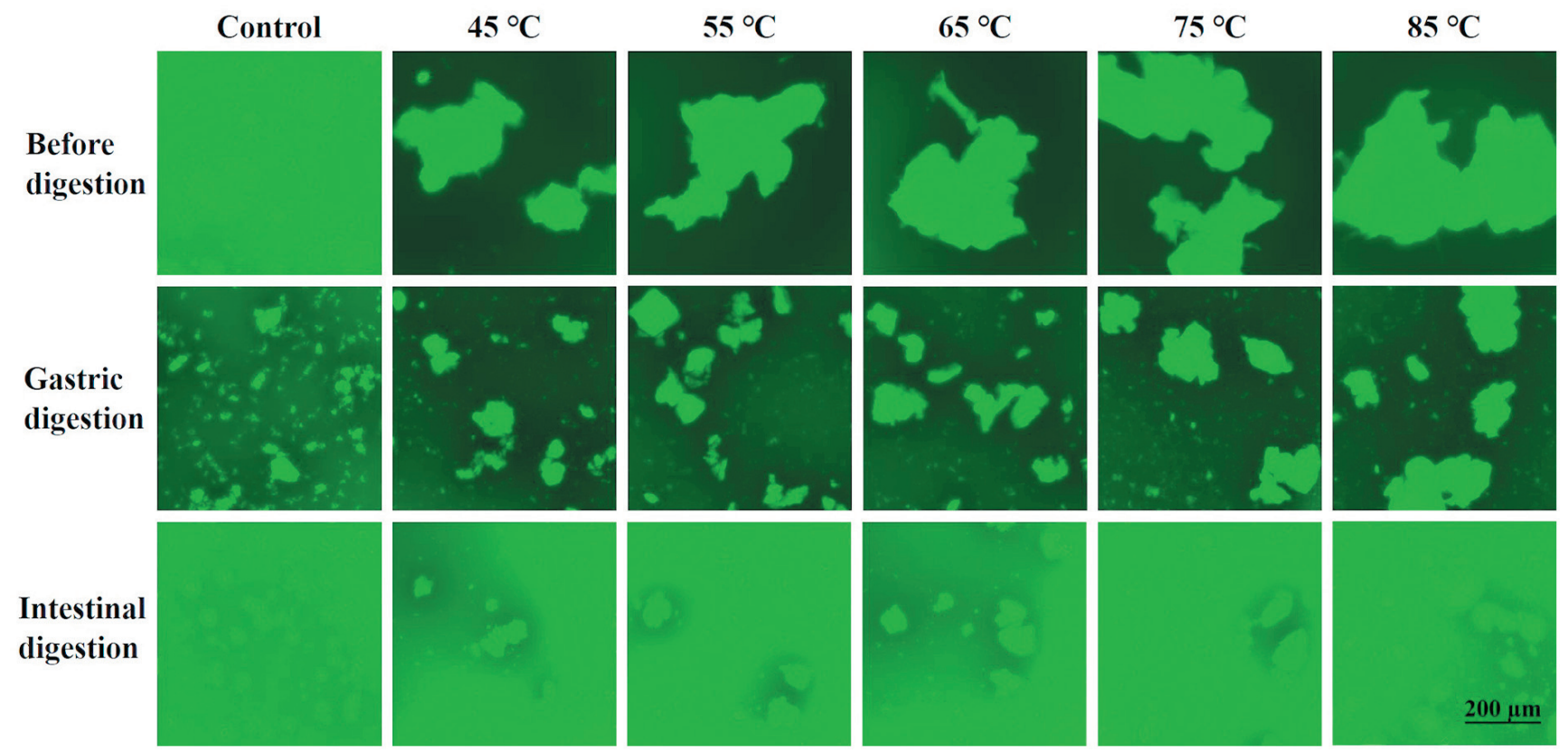

FIGURE 5. Micrographs of the raw (control) and steamed large-mouth bass with different core temperatures at different digestive phases. The magnification was $200 \times$ and the scale bar was $200 \mu \mathrm{m}$.

isfactory quality should not exceed $5 \log \mathrm{CFU} / \mathrm{g}$ [Microbiological Guidelines, 2007]. In our study, the aerobic count in the raw fish meat was only $3.2 \log \mathrm{CFU} / \mathrm{g}$ (Table 4). It decreased significantly when the steam core temperature reached $65^{\circ} \mathrm{C}(p<0.05)$, and declined to the lowest at $75^{\circ} \mathrm{C}$ and $85^{\circ} \mathrm{C}$, which suggested the effective role of steaming treatment in improving the food safety. The count of total coliforms in the raw fish meat was $1.2 \log \mathrm{CFU} / \mathrm{g}$, while they were not detected after steaming, even though the core temperature was only $45^{\circ} \mathrm{C}$. And the generic $E$. coli was not detected in both raw and steamed samples. In addition, as recommended by USDA-FDA [2011], the safe minimum internal temperature for fish cooking should be $145^{\circ} \mathrm{F}$ (around $63^{\circ} \mathrm{C}$ ).

\section{CONCLUSION}

Steaming, especially when the core temperature was above $75^{\circ} \mathrm{C}$, significantly increased cooking loss of large-mouth bass, which was accompanied with a significant increase of protein oxidation and aggregation, which further caused an increased particle size and decreased in vitro digestibility of fish meat. Unpleasant fishy smell often presents in less cooked fish. Analysis of volatile compounds revealed that odor profile was clearly altered when the core temperature increased from $65^{\circ} \mathrm{C}$ to $75^{\circ} \mathrm{C}$, likely due to the oxidative degradation of fatty acids. Core temperature of $65^{\circ} \mathrm{C}$ or above also enhanced food safety from the microbiological aspect as the aerobic count decreased significantly as compared to the raw samples. In addition, total coliforms and generic E. coli were not detected in all steamed fish samples. Therefore, to ensure safety, pleasant flavor and minimal protein oxidation, the core temperature between $65^{\circ} \mathrm{C}$ and $75^{\circ} \mathrm{C}$ was recommended for the steamed large-mouth bass.

\section{RESEARCH FUNDING}

The authors gratefully acknowledge the subsidization from the Natural Science Foundation of China (31901758), the Natural Science Foundation of Jiangsu Province of China (BK20190591), and by China Postdoctoral Science Foundation (2019M651707). This work was also supported by 111 Project (BP0719028), and the National Firstclass Discipline Program of Food Science \& Technology (JURSTR20180201).

\section{CONFLICT OF INTERESTS}

The authors confirm that they have no conflicts of interest with respect to the work described in this paper.

\section{REFERENCES}

1. Bastías, J.M., Balladares, P., Acuña, S., Quevedo, R., Muñoz, O. (2017). Determining the effect of different cooking methods on the nutritional composition of salmon (Salmo salar) and chilean jack mackerel (Trachurus murphyi) fillets. PLoS ONE, 12(7), art. no. e0180993.

2. Bax, M.L., Aubry, L., Ferreira, C., Daudin, J.D., Gatellier, P., Rémond, D., Santé-Lhoutellier, V. (2012). Cooking temperature is a key determinant of in vitro meat protein digestion rate: Investigation of underlying mechanisms. Journal of Agricultural and Food Chemistry, 60(10), 2569-2576.

3. Benjakul, S., Seymour, T.A., Morrissey, M.T., An, H.J. (1997). Physicochemical changes in Pacific whiting muscle proteins during iced storage. Journal of Food Science, 62 (4), 729-733.

4. Berlett, B.S., Stadtman, E.R. (1997). Protein oxidation in aging, disease, and oxidative stress. Journal of Biological Chemistry, 272(33), 20313-20316. 
5. Chaiyasit, W., Elias, R.J., McClements, D.J., Decker, E.A. (2007). Role of physical structures in bulk oils on lipid oxidation. Critical Reviews in Food Science and Nutrition, 47(3), 299-317.

6. Dong, X., Fu, H., Feng, D., He, B., Jiang, D., Qin, L., Qi, H. (2018). Oxidative stress-induced textural and biochemical changes of scallop Patinopecten yessoensis adductor muscle under heat treatment. International Journal of Food Properties, 2l(1), 1054-1066.

7. Estévez, M., Luna, C. (2017). Dietary protein oxidation: A silent threat to human health? Critical Reviews in Food Science and $\mathrm{Nu}$ trition, 57(17), 3781-3793.

8. Flaskerud, K., Bukowski, M., Golovko, M., Johnson, L., Brose, S., Ali, A., Cleveland, B., Picklo, M.Sr., Raatz, S. (2017). Effects of cooking techniques on fatty acid and oxylipin content of farmed rainbow trout (Oncorhynchus mykiss). Food Science \& Nutrition, 5(6), 1195-1204.

9. Ganhão, R., Estévez, M., Morcuende, D. (2011). Suitability of the TBA method for assessing lipid oxidation in a meat system with added phenolic-rich materials. Food Chemistry, 126(2), 772-778.

10. Guyon, C., Meynier, A., Lamballerie, M.D. (2016). Protein and lipid oxidation in meat: A review with emphasis on high-pressure treatments. Trends in Food Science \& Technology, 50, 131-143.

11. Hu, L., Ren, S., Shen, Q., Chen, J., Ye, X., Ling, J. (2017). Proteomic study of the effect of different cooking methods on protein oxidation in fish fillets. RSC Advances, 7(44), 27496-27505.

12. Hu, L., Ren, S., Shen, Q., Ye, X., Chen, J., Ling, J. (2018). Protein oxidation and proteolysis during roasting and in vitro digestion of fish (Acipenser gueldenstaedtii). Journal of the Science of Food and Agriculture, 98(14), 5344-5351.

13. Kjærsgård, V.H., Nørrelykke, M.R., Baron, C.P., Jessen, F. (2006). Identification of carbonylated protein in frozen rainbow trout (Oncorhynchus mykiss) fillets and development of protein oxidation during frozen storage. Journal of Agricultural and Food Chemistry, 54(25), 9437-9446.

14. Korzeniowska, M., Cheung, I.W.Y., Li-Chan, E.C.Y. (2013). Effects of fish protein hydrolysate and freeze-thaw treatment on physicochemical and gel properties of natural actomyosin from Pacific cod. Food Chemistry, 138(2-3), 1967-1975.

15. Li, C., Wang, D., Xu, W., Gao, F., Zhou, G. (2013). Effect of final cooked temperature on tenderness, protein solubility and microstructure of duck breast muscle. LWT-Food Science and Technology, 5l(1), 266-274.

16. Lorenzo, J.M., Domínguez, R. (2014). Cooking losses, lipid oxidation and formation of volatile compounds in foal meat as affected by cooking procedure. Flavour and Fragrance Journal, 29(4), 240-248.

17. Lund, M.N., Heinonen, M., Baron, C.P., Estévez, M. (2011). Protein oxidation in muscle foods: A review. Molecular Nutrition and Food Research, 55(1), 83-95.

18. Maulvault, A.L., Anacleto, P., Machado, R., Amaral, A., Carvalho, M.L., Lourenço, H.M., Nunes, M.L., Marques, A. (2012). Effect of sex, maturation stage and cooking methods on the nutritional quality and safety of black scabbard fish (Aphanopus carbo Lowe, 1839). Journal of the Science of Food and Agriculture, 92(7), 1545-1553.

19. Mi, H., Guo, X., Li, J. (2016). Effect of 6-gingerol as natural antioxidant on the lipid oxidation in red drum fillets during refrigerated storage. LWT - Food Science and Technology, 74, 70-76.
20. Microbiological Guidelines (2007). Microbiological guidelines for ready-to-eat food. Retrieved from [https://www.cfs.gov.hk/english/whatsnew/whatsnew_act/files/MBGL_RTE\%20food_e.pdf].

21. Minekus, M., Alminger, M., Alvito, P., Ballance, S., Bohn, T., Bourlieu, C., Carrière, F., Boutrou, R., Corredig, M., Dupont, D., Dufour, C., Egger, L., Golding, M., Karakaya, S., Kirkhus, B., Le Feunteun, S., Lesmes, U., Macierzanka, A., Mackie, A., Marze, S., McClements, D.J., Ménard, O., Recio I., Santos, C.N., Singh, R.P., Vegarud, G.E., Wickham, M.S.J., Weitschies, W., Brodkorb, A. (2014). A standardised static in vitro digestion method suitable for food - an international consensus. Food \& Function, 5(6), 1113-1124.

22. Schaich, K.M., Shahidi, F., Zhong, Y., Eskin, N.A.M. (2013). Lipid oxidation. In Biochemistry of Foods. 3rd edition, Elsevier, London, UK, pp. 419-478.

23. Shi, C., Guo, H., Wu, T., Tao, N., Wang, X., Zhong, J. (2019). Effect of three types of thermal processing methods on the lipidomics profile of tilapia fillets by UPLC-Q-Extractive Orbitrap mass spectrometry. Food Chemistry, 298, art. no. e125029.

24. Silva, F.A.P., Ferreira, V.C.S., Madruga, M.S., Estévez, M. (2016). Effect of the cooking method (grilling, roasting, frying and sous-vide) on the oxidation of thiols, tryptophan, alkaline amino acids and protein cross-linking in jerky chicken. Journal of Food Science and Technology, 53(8), 3137-3146.

25. Sobral, M.M.C., Cunha, S.C., Faria, M.A., Ferreira, I.M. (2018). Domestic cooking of muscle foods: Impact on composition of nutrients and contaminants. Comprehensive Reviews in Food Science and Food Safety, 17(2), 309-333.

26. Soladoye, O.P., Juarez, M.L., Aalhus, J.L., Shand, P., Estévez, M. (2015). Protein oxidation in processed meat: Mechanisms and potential implications on human health. Comprehensive Reviews in Food Science and Food Safety, 14(2), 106-122.

27. Souza, H.A.L., Bragagnolo, N. (2014). New method for the extraction of volatile lipid oxidation products from shrimp by head-space-solid-phase microextraction-gas chromatography-mass spectrometry and evaluation of the effect of salting and drying. Journal of Agricultural and Food Chemistry, 62(3), 590-599.

28. Sun, W., Zhao, M., Yang, B., Zhao, H., Cui, C. (2011). Oxidation of sarcoplasmic proteins during processing of Cantonese sausage in relation to their aggregation behaviour and in vitro digestibility. Meat Science, 88(3), 462-467.

29. USDA-FDA. (2011). Food Safety for People with Diabetes, [https://www.fda.gov/media/120978/download, last accessed on 30.07.2020].

30. Visessanguan, W., Benjakul, S., Riebroy, S., Thepkasikul, P. (2004). Changes in composition and functional properties of proteins and their contributions to Nham characteristics. Meat Science, 66(3), 579-588.

31. Wang, K., Yang, H., Bao, Y., Feng, R., Wang, Y., Chen, D., Zhou, P. (2019). Effect of different core temperatures on the quality of steam-cooked Micropterus salmoides. Science \& Technology of Food Industry, 40(15), 20-27 (in Chinese; English abstract).

32. Wen, S., Zhou, G., Li, L., Xu, X., Yu, X., Bai, Y., Li, C. (2015). Effect of cooking on in vitro digestion of pork proteins: A peptidomic perspective. Journal of Agricultural and Food Chemistry, 63(1), 250-261.

33. Yu, D., Xu, Y., Regenstein, J.M., Xia, W., Yang, F., Jiang, Q., Wang, B. (2018). The effects of edible chitosan-based coatings on flavor quality of raw grass carp (Ctenopharyngodon idellus) fillets during refrigerated storage. Food Chemistry, 242, 412-420. 
34. Yuan, Y., Chen, Y.J., Liu, Y.J., Yang, H.J., Liang, G.Y., Tian, L.X. (2014). Dietary high level of vitamin premix can eliminate oxidized fish oil-induced oxidative damage and loss of reducing capacity in juvenile largemouth bass (Micropterus salmoides). Aquaculture Nutrition, 20(2), 109-117.

35. Zhang, L., Li, Q., Jia, S., Huang, Z., Luo, Y. (2018). Effect of different stunning methods on antioxidant status, in vivo myofibrillar protein oxidation, and the susceptibility to oxidation of silver carp (Hypophthalmichthys molitrix) fillets during $72 \mathrm{~h}$ postmortem. Food Chemistry, 246(25), 121-128.

36. Zhou, C., Pan, D., Sun, Y., Li, C., Xu, X., Cao, J., Zhou, G. (2018). The effect of cooking temperature on the aggregation and digestion rate of myofibrillar proteins in Jinhua ham. Journal of the Science of Food and Agriculture, 98(9), 3563-3570.

Submitted: 6 May 2020. Revised: 3 July 2020. Accepted: 27 July 2020. Published on-line: 25 August 2020. 